Article

\title{
Non-Invasive Assessment of Locally Overexpressed Human Adenosine 2A Receptors in the Heart of Transgenic Mice
}

\author{
Daniel Gündel ${ }^{1, *(\mathbb{C})}$, Thu Hang Lai ${ }^{1,2}{ }^{\mathbb{C}}$, Sladjana Dukic-Stefanovic ${ }^{1}$, Rodrigo Teodoro ${ }^{1}(\mathbb{D}$,

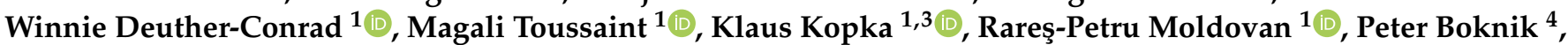 \\ Britt Hofmann ${ }^{5}$, Ulrich Gergs ${ }^{6} \mathbb{C}^{\mathbb{D}}$, Joachim Neumann ${ }^{6,+}$ and Peter Brust ${ }^{1,7,+}$
}

Citation: Gündel, D.; Lai, T.H.; Dukic-Stefanovic, S.; Teodoro, R.; Deuther-Conrad, W.; Toussaint, M.; Kopka, K.; Moldovan, R.-P.; Boknik P.; Hofmann, B.; et al. Non-Invasive Assessment of Locally Overexpressed Human Adenosine 2A Receptors in the Heart of Transgenic Mice. Int. J. Mol. Sci. 2022, 23, 1025

https: / /doi.org/10.3390/ ijms23031025

Academic Editor: Katia Varani

Received: 21 December 2021

Accepted: 14 January 2022

Published: 18 January 2022

Publisher's Note: MDPI stays neutral with regard to jurisdictional claims in published maps and institutional affiliations.

Copyright: (C) 2022 by the authors. Licensee MDPI, Basel, Switzerland. This article is an open access article distributed under the terms and conditions of the Creative Commons Attribution (CC BY) license (https:// creativecommons.org/licenses/by/ $4.0 /)$.
1 Department of Neuroradiopharmaceuticals, Institute of Radiopharmaceutical Cancer Research, Research Site Leipzig, Helmholtz-Zentrum Dresden-Rossendorf, 04813 Leipzig, Germany; t.lai@hzdr.de (T.H.L.); s.dukic-stefanovic@hzdr.de (S.D.-S.); r.teodoro@hzdr.de (R.T.); w.deuther-conrad@hzdr.de (W.D.-C.); m.toussaint@hzdr.de (M.T.); k.kopka@hzdr.de (K.K.); r.moldovan@hzdr.de (R.-P.M.); p.brust@hzdr.de (P.B.)

2 Department of Research and Development, ROTOP Pharmaka Ltd., 01328 Dresden, Germany

3 Faculty of Chemistry and Food Chemistry, School of Science, Technical University Dresden, 01069 Dresden, Germany

4 Institute for Pharmacology and Toxicology, University of Muenster, 48149 Muenster, Germany; boknik@uni-muenster.de

5 Cardiac Surgery, Medical Faculty, Martin Luther University of Halle-Wittenberg, 06120 Halle, Germany; britt.hofmann@uk-halle.de

6 Institute for Pharmacology and Toxicology, Martin Luther University of Halle-Wittenberg, 06112 Halle, Germany; Ulrich.gergs@medizin.uni-halle.de (U.G.); joachim.neumann@medizin.uni-halle.de (J.N.)

7 The Lübeck Institute of Experimental Dermatology, University Medical Center Schleswig-Holstein, 23562 Lübeck, Germany

* Correspondence: d.guendel@hzdr.de; Tel.: +49-341-234179-4615

+ These authors contributed equally to this work.

Abstract: $A_{2 A}$ adenosine receptors $\left(A_{2 A}-A R\right)$ have a cardio-protective function upon ischemia and reperfusion, but on the other hand, their stimulation could lead to arrhythmias. Our aim was to investigate the potential use of the PET radiotracer $\left[{ }^{18} \mathrm{~F}\right] \mathrm{FLUDA}$ to non-invasively determine the $\mathrm{A}_{2 \mathrm{~A}^{-}}$ $\mathrm{AR}$ availability for diagnosis of the $\mathrm{A}_{2 \mathrm{~A}} \mathrm{R}$ status. Therefore, we compared mice with cardiomyocytespecific overexpression of the human $A_{2 A}-A R\left(A_{2 A}-A R T G\right)$ with the respective wild type (WT). We determined: (1) the functional impact of the selective $A_{2 A} R$ ligand FLUDA on the contractile function of atrial mouse samples, $(2)$ the binding parameters $\left(B_{\max \text { and }} K_{\mathrm{D}}\right)$ of $\left[{ }^{18}\right.$ F]FLUDA on mouse and human atrial tissue samples by autoradiographic studies, and (3) investigated the in vivo uptake of the radiotracer by dynamic PET imaging in $\mathrm{A}_{2 \mathrm{~A}}$-AR TG and WT. After $\mathrm{A}_{2 \mathrm{~A}}-\mathrm{AR}$ stimulation by the $\mathrm{A}_{2 \mathrm{~A}}$-AR agonist CGS 21680 in isolated atrial preparations, antagonistic effects of FLUDA were found in $\mathrm{A}_{2 \mathrm{~A}}$-AR-TG animals but not in WT. Radiolabelled [ $\left.{ }^{18} \mathrm{~F}\right]$ FLUDA exhibited a $K_{\mathrm{D}}$ of $5.9 \pm 1.6 \mathrm{nM}$ and a $B_{\text {max }}$ of $455 \pm 78 \mathrm{fmol} / \mathrm{mg}$ protein in cardiac samples of $A_{2 A}-A R T G$, whereas in WT, as well as in human atrial preparations, only low specific binding was found. Dynamic PET studies revealed a significantly higher initial uptake of $\left[{ }^{18} \mathrm{~F}\right] \mathrm{FLUDA}$ into the myocardium of $\mathrm{A}_{2 \mathrm{~A}}$-AR TG compared to WT. The $h A_{2 A}$-AR-specific binding of $\left[{ }^{18}\right.$ F]FLUDA in vivo was verified by pre-administration of the highly affine $\mathrm{A}_{2 \mathrm{~A}} \mathrm{AR}$-specific antagonist istradefylline. Conclusion: $\left[{ }^{18} \mathrm{~F}\right] \mathrm{FLUDA}$ is a promising PET probe for the non-invasive assessment of the $A_{2 A}-A R$ as a marker for pathologies linked to an increased $\mathrm{A}_{2 \mathrm{~A}}$-AR density in the heart, as shown in patients with heart failure.

Keywords: $\left[{ }^{18}\right.$ F]FLUDA; $A_{2 A}$ adenosine receptor; PET; myocardium; heart failure

\section{Introduction}

Multiple effects of adenosine in humans and animals have been described for many years. In the heart, adenosine, potentially released from myocardial ATP, reduces the heart 
rate and dilates coronary arteries [1]. It elicits negative chronotropic (sinus node), negative dromotropic (AV-node), and negative inotropic (atrial tissue) effects in the hearts of mice and humans [1]. In the ventricle of most mammalian species, including humans, adenosine diminishes force only in the presence of cAMP-increasing agents, like $\beta$-adrenoceptor agonists or phosphodiesterase inhibitors. Adenosine binds to different adenosine receptors, which are classified into different subtypes $\left(A_{1}-A R, A_{2 A}-A R, A_{2 B}-A R\right.$, and $\left.A_{3}-A R\right)[1,2]$. They are located in the outer cell membrane of cardiomyocytes, endothelial cells, fibroblasts, erythrocytes, leucocytes, and smooth muscle cells and coupled to GTP-binding proteins to trigger intracellular signalling pathways. Thereby, the binding of adenosine to the highaffinity $\mathrm{A}_{1}-\mathrm{AR}$ and $\mathrm{A}_{2 \mathrm{~A}}-\mathrm{AR}$ regulates the intracellular cAMP content by opposing effects on the adenylyl cyclase activity $\left(\mathrm{A}_{1}-\mathrm{AR}\right.$ : inhibition, $\mathrm{A}_{2 \mathrm{~A}}$-AR: activation) $[3,4]$. Additionally, inotropic effects elicited by $\beta$-adrenergic stimulation (cAMP elevation) are antagonised by the $\mathrm{A}_{1}-\mathrm{AR}$ adenosine signalling in cardiomyocytes in the atrium and the ventricle $[5,6]$. The adenosine signalling by $\mathrm{A}_{2 \mathrm{~A}}$-AR not only attenuates the $\mathrm{A}_{1}$-AR signalling, but also leads to a dilatation of the cardiac vasculature [7] and could indirectly increase the contractility by increasing the oxygen supply [8]. Thus, the cardioprotective effects of adenosine may involve signalling via $A_{1}-A R$ and $A_{2 A}-A R$ [9].

Elevated $\mathrm{A}_{2 \mathrm{~A}}$-AR expression was found in the atrium of patients with atrial fibrillation $[10,11]$, while it was decreased in ventricular tissue of patients with chronic heart failure [12]. The beneficial effects of $\mathrm{A}_{2 \mathrm{~A}} \mathrm{AR}$ agonists, such as LASSBio-294, prevented cardiac dysfunction in a rat model [13]. Similar effects were found for the A2AAR agonists ATL-193 and ATL-146e in postischemic stunning of the myocardium in a canine model [14].

Obviously, the protective but also deleterious effects of adenosine depend not only on the plasma and interstitial concentrations of adenosine, but also on the expression and receptor density on cell membranes [15]. Therefore, non-invasive imaging of the cardiac $\mathrm{A}_{2 \mathrm{~A}} \mathrm{R}$ availability is a promising, non-invasive tool to stratify prognosis of cardiac damage, but also for the determination of the receptor occupancy by potential $A_{2 A}-A R$ agonists.

$\mathrm{A}_{2 \mathrm{~A}}-\mathrm{AR}$ imaging has successfully been performed in neurological disorders using positron emission tomography (PET) with $\left[{ }^{11} \mathrm{C}\right]$ preladenant and, recently, $\left[{ }^{18} \mathrm{~F}\right] \mathrm{MNI}-444$ in a clinical phase III study $[16,17]$. The $K_{\mathrm{i}}$ of $\left[{ }^{18} \mathrm{~F}\right] \mathrm{MNI}-444$ towards human $\mathrm{A}_{2 \mathrm{~A}}-\mathrm{AR}$ is comparably high $(2.8 \mathrm{nM})$ [17]. Hence, a striatum-to-cerebellum ratio (measure of specific binding) of about 12 was found at 60-70 min after injection in humans [17]. Our recently developed $\mathrm{A}_{2 \mathrm{~A}}$-AR-specific PET radiotracer [ $\left.{ }^{18} \mathrm{~F}\right] \mathrm{FLUDA}$ (human $\mathrm{A}_{2 \mathrm{~A}}$-AR: $K_{\mathrm{i}}=0.6 \mathrm{nM}$; human $\mathrm{A}_{1}$-AR: $K_{\mathrm{i}}=767 \mathrm{nM}$ ) appears highly suitable for the non-invasive $\mathrm{A}_{2 \mathrm{~A}}-\mathrm{AR}$ imaging of mice and piglet brains [18]. In terms of assessing the $A_{2 A}-A R$ availability in the heart, aiming at the visualisation of pathologically relevant changes, earlier attempts were performed by Ishiwata and colleagues using the $\mathrm{A}_{2 \mathrm{~A}}-\mathrm{AR}$ radioligands $\left[{ }^{11} \mathrm{C}\right] \mathrm{KF} 17837$ and $\left[{ }^{11} \mathrm{C}\right]$ TMSX (Figure 1 ) in rabbits and humans, whereat $\left[{ }^{11} \mathrm{C}\right] \mathrm{TMSX}$ revealed good properties for PET imaging and high plasma stability $[19,20]$.

With that regard, the aim of this study was to evaluate the potential of $\left[{ }^{18} \mathrm{~F}\right] \mathrm{FLUDA}$ for $\mathrm{A}_{2 \mathrm{~A}}$-AR imaging by PET in a mouse model with a functional myocardial overexpression of the human $\mathrm{A}_{2 \mathrm{~A}}-\mathrm{AR}$ [21]. 


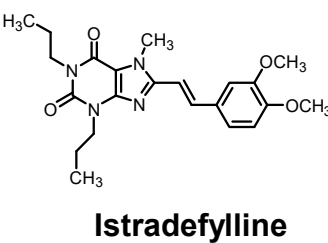

Istradefylline<smiles>CCCn1c(=O)c2c(nc(/C=C/c3ccc(OC)c(OC)c3)n2C)n(CCC)c1=O</smiles>

$\left.{ }^{11} \mathrm{C}\right] \mathrm{KF} 17837$<smiles>[2H]C([2H])([2H])C([2H])([2H])Oc1ccc(CCCn2ncc3c2nc(N)n2nc(-c4ccco4)nc32)cc1</smiles>

[18F]FLUDA<smiles>COc1cc(/C=C/c2nc3c(c(=O)n(C)c(=O)n3C)n2C)cc(OC)c1OC</smiles>

$\left.{ }^{[11} \mathrm{C}\right] \mathrm{TMSX}$

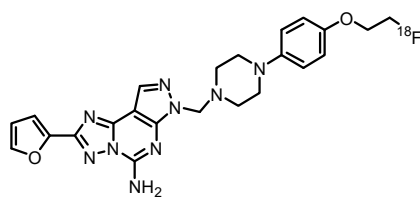

[18F]MNI-444

Figure 1. Chemical structures of $A_{2 A}-A R$ PET radioligands and the $A_{2 A}-A R$ antagonist istradefylline used in the present study.

\section{Results}

2.1. Impact of FLUDA on the Atrial Force of Contraction (FOC) in Electrically Stimulated Atrial Preparations

The yet unknown agonistic or antagonistic action of FLUDA towards the human $\mathrm{A}_{2 \mathrm{~A}}$-AR was investigated in electrically stimulated atrial preparations of wild-type mice (WT) and $h A_{2 A}-A R T G$ (Figure 2). As shown in Figure 2B, the FOC of WT was not changed after adding $10 \mu \mathrm{M}$ of the $\mathrm{A}_{2 \mathrm{~A}}-\mathrm{AR}$ agonist CGS 21680 (positive inotropic effect) to the organ bath. An anti-inotropic effect towards the human $\mathrm{A}_{2 \mathrm{~A}}-\mathrm{AR}$ was observed after the subsequent adding of $1 \mu \mathrm{M}$ FLUDA. The FOC was decreased by $15.0 \pm 2.4 \%$ in the $\mathrm{A}_{2 \mathrm{~A}^{-}}$ AR TG atria. Hence, these results revealed an antagonistic effect of FLUDA towards a stimulated $\mathrm{A}_{2 \mathrm{~A}}-\mathrm{AR}$.

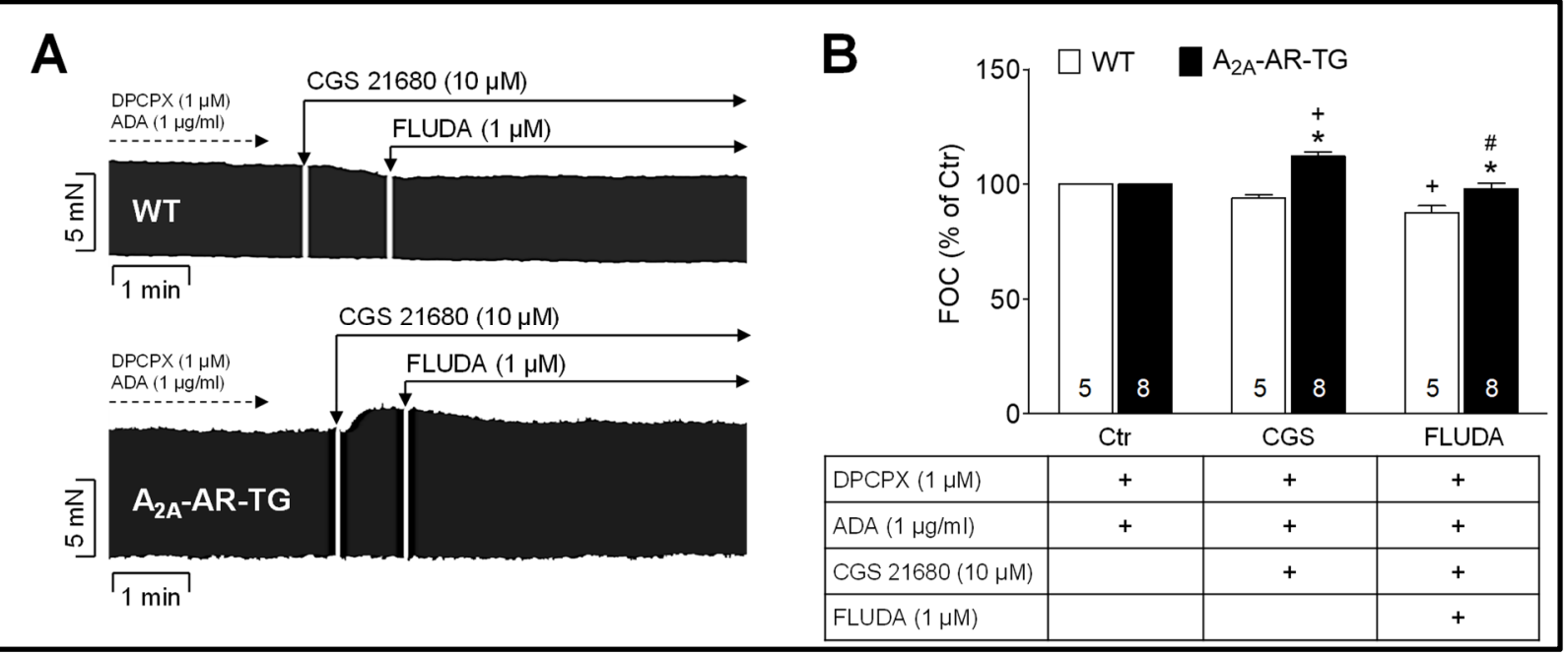

Figure 2. FLUDA $(1 \mu \mathrm{M})$ inhibits the $A_{2 A}-A R$-dependent force of contraction (FOC) in isolated electrically driven left atria from $A_{2 A}$-AR transgenic mice $\left(A_{2 A}-A R-T G\right)$ but not from wild-type mice

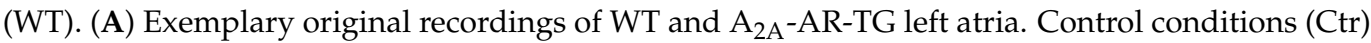
are the inhibition of $\mathrm{A}_{1}$-adenosine receptors by $1 \mu \mathrm{M}$ DPCPX and the degradation of extracellular adenosine by $1 \mu \mathrm{g} / \mathrm{mL}$ adenosine deaminase (ADA). Induction of atrial contraction was achieved by the $A_{2 A}$-AR agonist CGS $21680(10 \mu \mathrm{M})$. (B) Quantification of left atrial force. Data are means \pm SEM; numbers in columns are numbers of atrial preparations and + marks the added substance; ${ }^{*} p<0.05$ vs. WT; ${ }^{+} p<0.05$ vs. Ctr; $\# p<0.05$ vs. CGS (ANOVA). 


\subsection{In Vitro Binding of $\left[{ }^{18} F\right] F L U D A$ to the $A_{2 A}$-AR in Heart Samples}

We performed competition assays to determine the $\mathrm{A}_{2 \mathrm{~A}}$-AR specificity of $\left[{ }^{18} \mathrm{~F}\right] \mathrm{FLUDA}$ towards the heart tissue of WT and $\mathrm{A}_{2 \mathrm{~A}} \mathrm{AR}$ TG (Figure 3). In cardiac cryosections of WT, non-homologous competition with ZM 241385 revealed a specific $\mathrm{A}_{2 \mathrm{~A}}$-AR binding of $\left[{ }^{18} \mathrm{~F}\right]$ FLUDA of $24.6 \pm 9.6 \%$ (Figure $3 \mathrm{~A}$ ). However, the low signal of total binding, as well as the homologous competition with FLUDA, suggests a very low $A_{2 A}-A R$ density, preventing the determination of the endogenous $\mathrm{A}_{2 \mathrm{~A}}$-AR receptor density $B_{\max }$. In cardiac cryosections of $\mathrm{A}_{2 \mathrm{~A}}$-AR TG, non-homologous competition with ZM241385 revealed a specific binding of $69.0 \pm 6.6 \%$ (Figure $3 \mathrm{~A}$ ). A $B_{\max }$ of $455 \pm 78 \mathrm{fmol} / \mathrm{g}$ wet weight and a $K_{\mathrm{D}}$ of $5.9 \pm 1.6 \mathrm{nM}$ was determined (Figure 3B). Notably, the specific binding of $\left[{ }^{18}\right.$ F]FLUDA in muscle and lung tissues were comparable in WT and $\mathrm{A}_{2 \mathrm{~A}}-\mathrm{AR}$ TG (Figure S1).

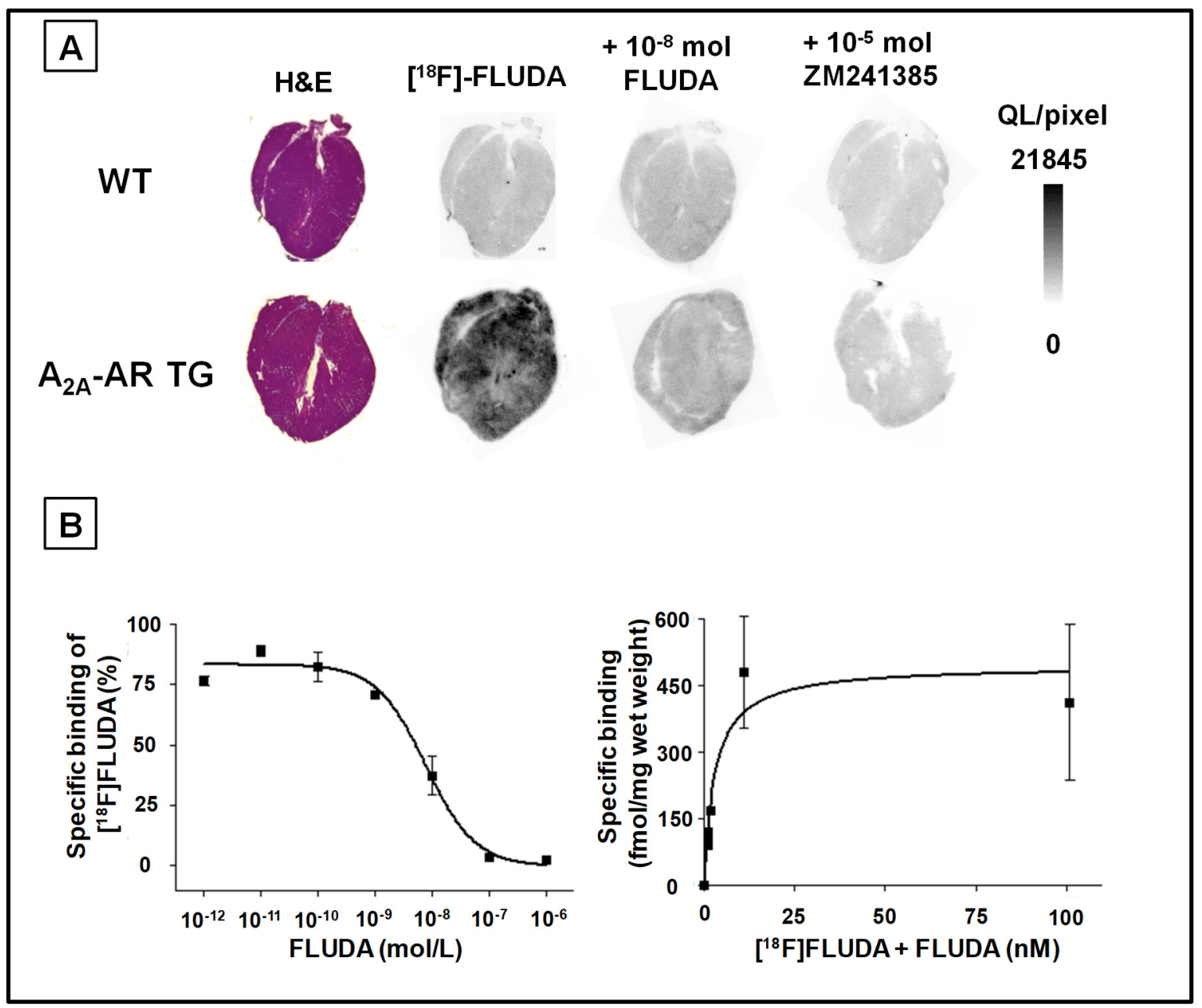

Figure 3. Representative in vitro autoradiographic images of the binding pattern of $\left[{ }^{18} \mathrm{~F}\right] \mathrm{FLUDA}$ mouse heart slices. (A) Hematoxylin/eosin staining ( $\mathrm{H} \& \mathrm{E})$, total binding of $\left[{ }^{18} \mathrm{~F}\right] \mathrm{FLUDA}$, homologous (FLUDA), and non-homologous (ZM 241385) displacement of [ ${ }^{18}$ F]FLUDA; (B) representative homologous competition curve of [18F]FLUDA and the saturation curve transformed from competition curve from $\mathrm{A}_{2 \mathrm{~A}}$-AR TG hearts. $K_{\mathrm{D}}$ and $B_{\max }$ were calculated from the homologous competition of $\left[{ }^{18}\right.$ F]FLUDA with FLUDA by the Cheng-Prusoff equation.

\subsection{In Vitro Binding Studies of $\left[{ }^{18}\right.$ F]FLUDA in Human Atrial Samples}

In a preliminary study, we used cryosections of human atrial samples of subjects without any diagnosed heart failure for autoradiography with $\left[{ }^{18} \mathrm{~F}\right]$ FLUDA and determined an $\mathrm{A}_{2 \mathrm{~A}}$-AR-specific binding of $36.3 \pm 5.3 \%(n=2)$ (Figure 4 ), which is comparable to the values determined in the WT group of mice, representing a low $\mathrm{A}_{2 \mathrm{~A}}-\mathrm{AR}$ availability in the healthy heart tissue. 


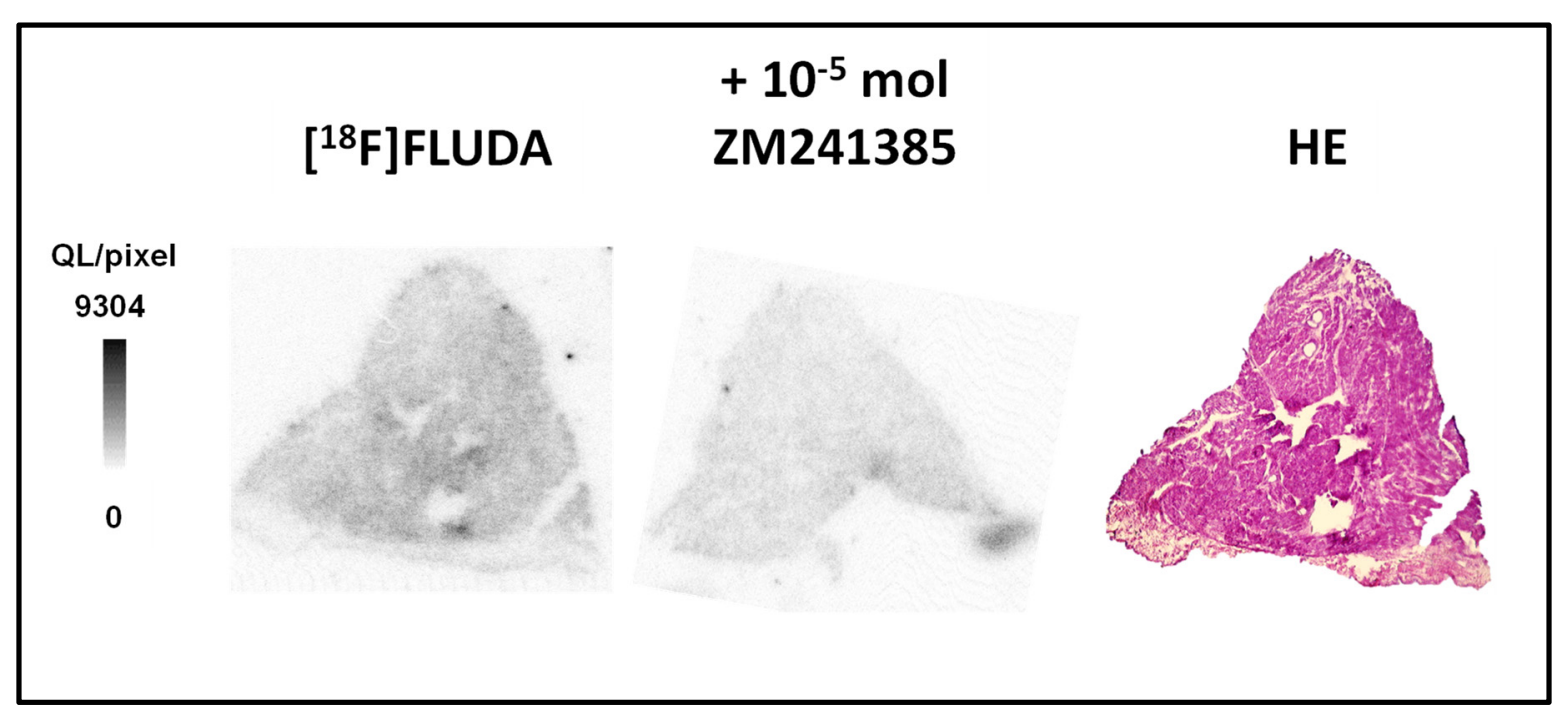

Figure 4. Representative in vitro autoradiographic images of $\left[{ }^{18} \mathrm{~F}\right] \mathrm{FLUDA}$ binding to human atrial samples, showing the total binding and displacement of the radioligand by the $\mathrm{A}_{2 \mathrm{~A}}$-AR-specific receptor antagonist ZM241385, as well as the corresponding HE staining of an atrial cryosection of a patient without heart failure.

2.4. In Vivo Uptake into the Heart and Other Tissues of $\left[{ }^{18}\right.$ F]FLUDA in WT and $A_{2 A}-A R$ TG under Baseline Conditions and after Blocking with Tozadenant and Istradefylline

Based on the promising in vitro observations, we performed PET studies over 60 min under baseline and blocking conditions to determine the biodistribution of $\left[{ }^{18} \mathrm{~F}\right] \mathrm{FLUDA}$ (Figures 5,S2-S5).

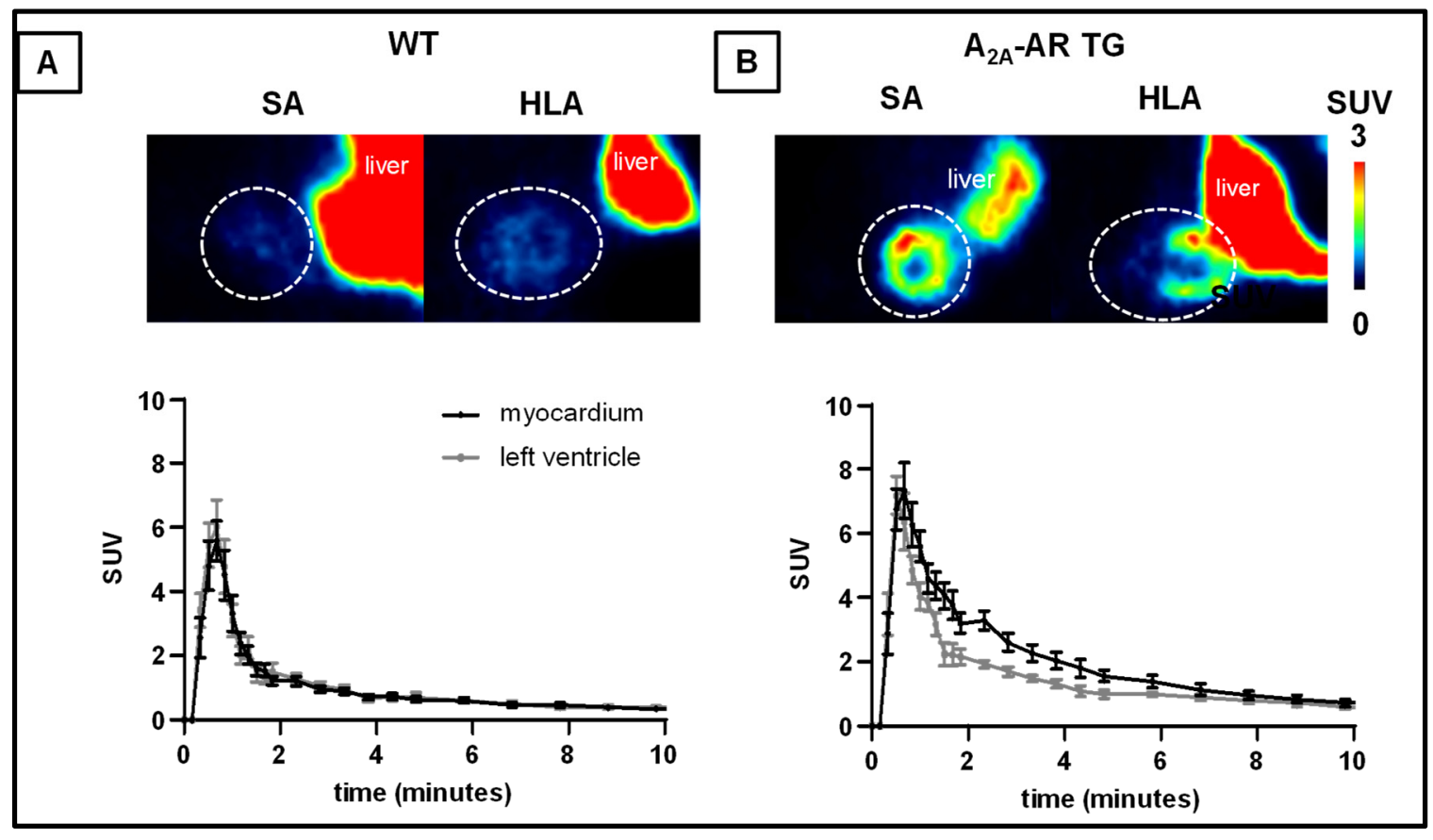

Figure 5. In vivo evaluation of the $\left[{ }^{18} \mathrm{~F}\right] \mathrm{FLUDA}$ biodistribution in the abdominal heart region by PET imaging. Images show the cardiac planes averaged from 1 to $10 \mathrm{~min}$ p.i. in the short axis (SA) and horizontal long axis (HLA) of averaged time frame between three and ten minutes after administration of $\left[{ }^{18}\right.$ F]FLUDA in (A) WT and (B) $A_{2 A}-A R$ TG. The heart region is marked with a dotted circle. Mice were pre-treated with vehicle $10 \mathrm{~min}$ prior to radiotracer application. Lookup-table decodes for the mean activity concentration given in standardised uptake values (SUV). 
Under baseline conditions, we observed an increased initial uptake (1 to 10 min p.i.) of $\left[{ }^{18} \mathrm{~F}\right]$ FLUDA in the myocardium of the $\mathrm{A}_{2 \mathrm{~A}}$-AR TG compared to WT (Figure 5). The analysis of the time-activity curves (TACs) (Figure 5, Table 1) revealed an earlier timeto-peak value in the blood compartment $(-0.2 \mathrm{~min}, p=0.011)$ and a higher TAC peak value in the myocardium of $\mathrm{A}_{2 \mathrm{~A}}-\mathrm{AR}$ TG (+10.4\%) compared to WT. Hence, the integrated activity concentration over time was higher in both compartments. In the initial phase, a 2.3 times higher $A U C$ value $\left(\mathrm{AUC}_{1-10}, p<0.001\right)$ was found in the myocardium, while it was 1.6 times higher $\left(\mathrm{AUC}_{1-10}, p=0.004\right)$ in the blood, as a result of the functional overexpression of the $\mathrm{hA}_{2 \mathrm{~A}}-\mathrm{AR}$. To normalise for unspecific physiological effects, $\mathrm{AUC}_{1-10}$ ratios (SUVr) of the myocardium to blood (Figure 6C, Table 3) and myocardium to muscle (Table 3) were calculated. They confirmed the increased uptake of $\left[{ }^{18} \mathrm{~F}\right] \mathrm{FLUDA}$ into the myocardium of $\mathrm{A}_{2 \mathrm{~A}}-\mathrm{AR}$ TG compared to the WT under baseline conditions. Other tissues showed comparable SUVrs in WT and $\mathrm{A}_{2 \mathrm{~A}} \mathrm{AR}$ TG under baseline conditions, suggesting a negligible impact of the functional $\mathrm{hA}_{2 \mathrm{~A}}-\mathrm{AR}$ overexpression in the myocardium on the pharmacokinetics of the radiotracer.

Table 1. Non-compartmental analysis of $\left[{ }^{18}\right.$ F]FLUDA showing the time to peak, the time-activity curve peak value (TAC peak value), the accumulated uptake from 0 to $60 \mathrm{~min}\left(\mathrm{AUC}_{0-60}\right)$, and from the initial $10 \mathrm{~min}\left(\mathrm{AUC}_{1-10}\right)$ p.i. in investigated tissues of the WT $(n=5)$ vs. $\mathrm{A}_{2 \mathrm{~A}}-\mathrm{AR}$ TG $(n=6)$.

\begin{tabular}{|c|c|c|c|c|c|c|c|c|c|c|c|c|}
\hline \multirow[t]{2}{*}{ Tissue } & \multicolumn{3}{|c|}{$\begin{array}{l}\text { Time to Peak } \\
(\text { min) }\end{array}$} & \multicolumn{3}{|c|}{$\begin{array}{c}\text { TAC Peak Value } \\
\text { (SUV) }\end{array}$} & \multicolumn{3}{|c|}{$\begin{array}{c}\mathrm{AUC}_{0-60} \\
(\mathrm{SUV} \cdot \mathrm{min})\end{array}$} & \multicolumn{3}{|c|}{$\begin{array}{l}\mathrm{AUC}_{1-10} \\
(\mathrm{SUV} \cdot \mathrm{min})\end{array}$} \\
\hline & WT & TG & $p$-Value & WT & TG & $p$-Value & WT & TG & $p$-Value & WT & TG & $p$-Value \\
\hline Myocardium & $0.6 \pm 0.1$ & $0.6 \pm 0.0$ & 0.105 & $6.3 \pm 0.6$ & $8.1 \pm 0.7$ & 0.0437 & $19.6 \pm 2.0$ & $35.0 \pm 3.1$ & 0.001 & $8.4 \pm 0.9$ & $19.3 \pm 2.2$ & $<0.001$ \\
\hline Blood & $0.7 \pm 0.0$ & $0.5 \pm 0.0$ & 0.011 & $6.9 \pm 0.9$ & $7.7 \pm 0.7$ & 0.242 & $20.4 \pm 2.4$ & $29.0 \pm 1.8$ & 0.008 & $8.6 \pm 1.2$ & $13.9 \pm 1.1$ & 0.004 \\
\hline Muscle & $3.3 \pm 1.0$ & $4.0 \pm 0.9$ & 0.303 & $0.5 \pm 0.1$ & $0.5 \pm 0.1$ & 0.327 & $9.6 \pm 1.4$ & $12.1 \pm 1.9$ & 0.153 & $3.8 \pm 0.5$ & $4.7 \pm 0.8$ & 0.175 \\
\hline Lung & $0.5 \pm 0.1$ & $0.5 \pm 0.0$ & 0.500 & $4.2 \pm 0.4$ & $4.7 \pm 0.4$ & 0.243 & $5.4 \pm 0.5$ & $17.8 \pm 3.7$ & 0.135 & $7.5 \pm 0.7$ & $7.3 \pm 1.5$ & 0.128 \\
\hline Liver & $3.5 \pm 0.5$ & $5.1 \pm 1.3$ & 0.123 & $6.7 \pm 1.1$ & $6.1 \pm 0.5$ & 0.313 & $126 \pm 17$ & $143 \pm 9$ & 0.200 & $\begin{array}{c}74.4 \pm \\
9.3\end{array}$ & $61.5 \pm 4.4$ & 0.119 \\
\hline
\end{tabular}

mean \pm SEM; $p$-value-Student's $t$-Test.

For blocking studies, the $\mathrm{A}_{2 \mathrm{~A}}-\mathrm{AR}$-specific inhibitor istradefylline (Figure 1) was injected $5 \mathrm{~min}$ before the radiotracer to prove the $\mathrm{A}_{2 \mathrm{~A}}$-AR-specific uptake of $\left[{ }^{18} \mathrm{~F}\right] \mathrm{FLUDA}$ into the myocardium (Figure 6, Tables 2 and 3). In WT, the time to peak in the blood compartment of the left ventricle was earlier compared to the baseline conditions $(p=0.017)$, whereas the TAC peak value in the muscle was slightly increased (SUV of $0.5 \pm 0.1$ vs. $0.8 \pm 0.1, p=0.027)$ compared to baseline WT. However, we found no significant changes in the $\mathrm{AUC}_{1-10}$ and $\mathrm{AUC}_{0-60}$ for these and other investigated tissues in comparison to the untreated WT. In $\mathrm{A}_{2 \mathrm{~A}}$-AR TG, pre-injection of istradefylline abolished the increased uptake of $\left[{ }^{18} \mathrm{~F}\right]$ FLUDA into the myocardium, as shown by the significant reduction of the $\mathrm{AUC}_{1-10}$, about 0.6 times ( $p=0.032$ vs. WT). These results were validated by the normalisation of the $\mathrm{AUC}_{1-10}$ of the tissues to the blood compartment, as well as to muscle. It was apparent that tissue normalisation to the blood compartment was less prone to fluctuation compared to the muscle, as shown by the SEM values (Table 3); thus, the blood compartment seems more suitable as a reference tissue. Additionally, in the more sensitive ex vivo autoradiography studies, the increased uptake of $\left[{ }^{18} \mathrm{~F}\right] \mathrm{FLUDA}$ in the murine hearts of $\mathrm{A}_{2 \mathrm{~A}}$-AR TG was found even fifteen minutes post-injection and was blocked by pre-administration of istradefylline (Figure S3). 


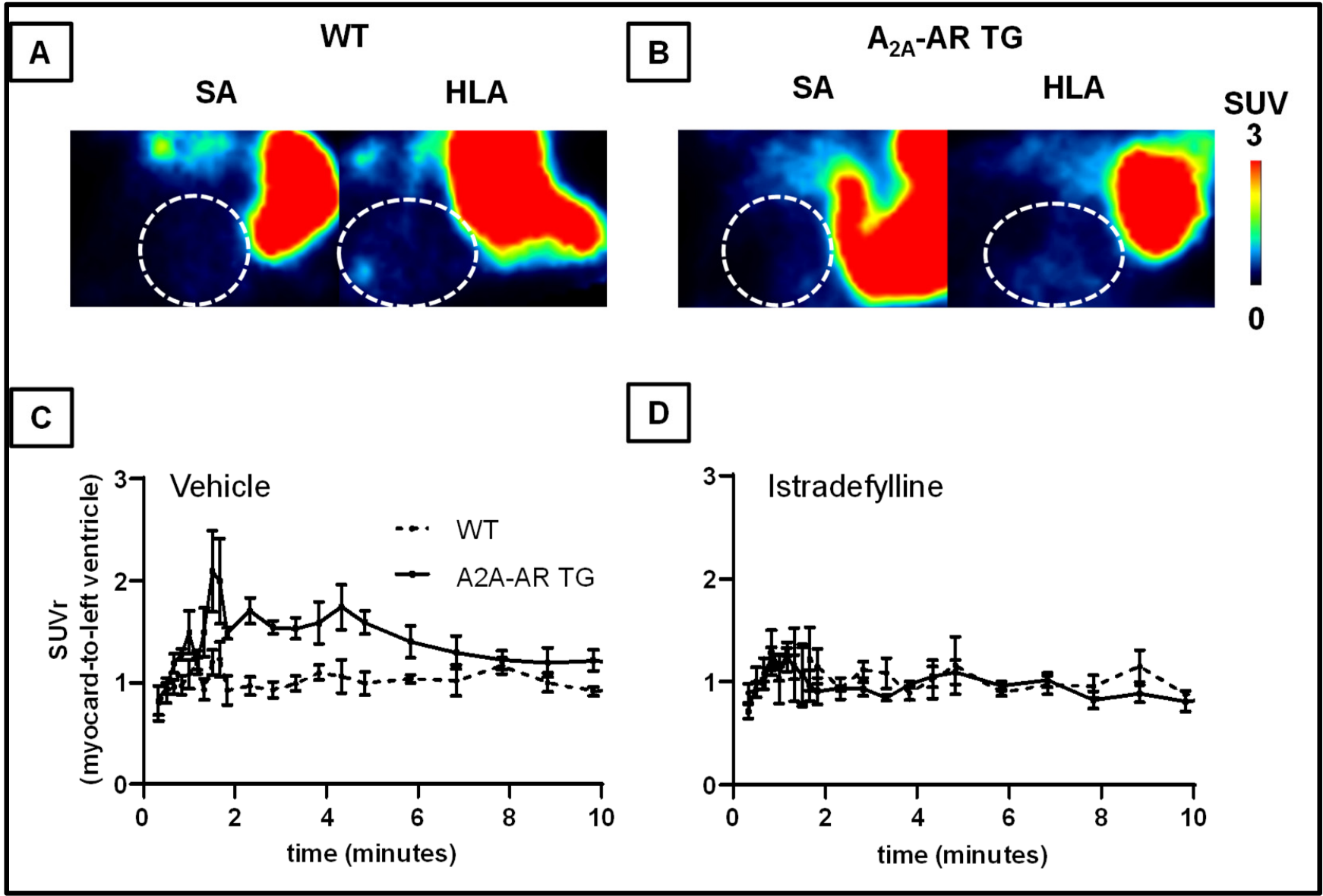

Figure 6. $\left[{ }^{18} \mathrm{~F}\right]$ FLUDA time-activity curves (TACs) in the myocardium and the left ventricle (blood compartment). Values are represented as mean standardised uptake values (SUV \pm S.E.M.) in the initial 10 min after radiotracer administration in (A) WT and (B) $\mathrm{A}_{2 \mathrm{~A}}$-AR TG $(n=)$. (C) TACs of the myocardium normalised to the blood compartment, and (D) to the muscle (SUVr \pm S.E.M.); $n=6-8$.

Table 2. Impact of pre-treatment with istradefylline $(n=3)$ on kinetic parameters in presented tissues of WT $(n=6)$ and $\mathrm{A}_{2 \mathrm{~A}}$-AR TG shown in \% of control.

\begin{tabular}{|c|c|c|c|c|c|c|c|c|c|}
\hline \multirow{2}{*}{$\begin{array}{c}\mathrm{A}_{2 \mathrm{~A}}-\mathrm{AR} \\
\text { Group }\end{array}$} & \multirow{2}{*}{ Tissue } & \multicolumn{2}{|c|}{ Time to Peak } & \multicolumn{2}{|c|}{ TAC Peak Value } & \multicolumn{2}{|c|}{$\mathrm{AUC}_{0-60}$} & \multicolumn{2}{|c|}{$\mathrm{AUC}_{1-10}$} \\
\hline & & Istradyfelline & $p$-Value & Istradyfelline & $p$-Value & Istradyfelline & $p$-Value & Istradyfelline & $p$-Value \\
\hline \multirow{5}{*}{ WT } & Myocardium & $87 \pm 9$ & 0.175 & $130 \pm 18$ & 0.082 & $116 \pm 4$ & 0.166 & $87 \pm 9$ & 0.175 \\
\hline & Blood & $75 \pm 0$ & 0.017 & $125 \pm 11$ & 0.125 & $117 \pm 6$ & 0.179 & $106 \pm 6$ & 0.381 \\
\hline & Muscle & $44 \pm 21$ & 0.138 & $180 \pm 24$ & 0.027 & $119 \pm 17$ & 0.229 & $142 \pm 19$ & 0.061 \\
\hline & Lung & $84 \pm 11$ & 0.223 & $109 \pm 31$ & 0.364 & $131 \pm 32$ & 0.130 & $133 \pm 38$ & 0.146 \\
\hline & Liver & $100 \pm 25$ & 0.500 & $100 \pm 11$ & 0.499 & $83 \pm 3$ & 0.210 & $94 \pm 5$ & 0.410 \\
\hline \multirow{5}{*}{ TG } & Myocardium & $120 \pm 17$ & 0.107 & $91 \pm 15$ & 0.302 & $78 \pm 8$ & 0.083 & $61 \pm 9$ & 0.032 \\
\hline & Blood & $105 \pm 11$ & 0.313 & $98 \pm 9$ & 0.442 & $100 \pm 11$ & 0.500 & $90 \pm 9$ & 0.222 \\
\hline & Muscle & $58 \pm 13$ & 0.130 & $138 \pm 50$ & 0.211 & $84 \pm 14$ & 0.268 & $99 \pm 21$ & 0.483 \\
\hline & Lung & $116 \pm 11$ & 0.090 & $95 \pm 6$ & 0.380 & $102 \pm 2$ & 0.470 & $92 \pm 5$ & 0.401 \\
\hline & Liver & $54 \pm 12$ & 0.124 & $117 \pm 3$ & 0.090 & $95 \pm 5$ & 0.315 & $102 \pm 0$ & 0.431 \\
\hline
\end{tabular}


Table 3. Tissue uptake over time of $\left[{ }^{18}\right.$ F]FLUDA normalised to the left ventricle or the muscle in the initial phase from 1 to $10 \mathrm{~min}$ p.i. in the WT $(n=5)$ vs. $\mathrm{A}_{2 \mathrm{~A}}$-AR TG group $(n=6)$.

\begin{tabular}{|c|c|c|c|c|c|c|c|}
\hline \multirow[t]{2}{*}{ Treatment } & \multirow{2}{*}{ Tissue } & \multicolumn{3}{|c|}{ AUC $_{1-10}$ Ratio (Tissue-to-Left Ventricle) } & \multicolumn{3}{|c|}{ AUC $_{1-10}$ Ratio (Tissue-to-Muscle) } \\
\hline & & WT & $A_{2 A}-A R T G$ & $p$-Value & WT & $A_{2 A}-A R T G$ & $p$-Value \\
\hline \multirow{3}{*}{ Vehicle } & Myocardium & $1.0 \pm 0.0$ & $1.4 \pm 0.1$ & 0.001 & $2.4 \pm 0.5$ & $4.8 \pm 1.2$ & 0.028 \\
\hline & Lung & $0.7 \pm 0.1$ & $0.5 \pm 0.1$ & 0.081 & $1.5 \pm 0.2$ & $1.7 \pm 0.2$ & 0.297 \\
\hline & Liver & $7.8 \pm 1.0$ & $6.0 \pm 1.6$ & 0.190 & $20.6 \pm 2.8$ & $16.5 \pm 4.4$ & 0.223 \\
\hline \multirow{3}{*}{ Istradefylline } & Myocardium & $1.0 \pm 0.0$ & $0.9 \pm 0.1$ & 0.570 & $1.8 \pm 0.4$ & $3.0 \pm 1.1$ & 0.334 \\
\hline & Lung & $0.8 \pm 0.2$ & $0.6 \pm 0.1$ & 0.400 & $1.3 \pm 0.2$ & $1.6 \pm 0.3$ & 0.483 \\
\hline & Liver & $6.5 \pm 0.4$ & $5.2 \pm 0.8$ & 0.193 & $11.5 \pm 3.2$ & $14.6 \pm 2.7$ & 0.390 \\
\hline
\end{tabular}

mean \pm SEM; $p$-value-Student's $t$-test.

Hence, the high specific binding of $\left[{ }^{18} \mathrm{~F}\right] \mathrm{FLUDA}$ towards the overexpressed $\mathrm{hA}_{2 \mathrm{~A}}-\mathrm{AR}$ in the myocardium of mice, as shown by the in vitro autoradiography studies, could be validated in vivo by PET imaging.

\section{Discussion}

The present work demonstrates the usefulness of the new radiotracer $\left[{ }^{18} \mathrm{~F}\right] \mathrm{FLUDA}$ for specific $\mathrm{A}_{2 \mathrm{~A}}-\mathrm{AR}$ imaging by PET in cardiac tissue. We present evidence that (1) FLUDA is a functional antagonist towards the human $\mathrm{A}_{2 \mathrm{~A}}$-AR and (2) $\left[{ }^{18} \mathrm{~F}\right] \mathrm{FLUDA}$ binds specifically and with high binding affinity to the human $\mathrm{A}_{2 \mathrm{~A}}$ - $\mathrm{AR}$ in a mouse model with transgenic overexpression of the receptor in the cardiac tissue and also to $\mathrm{A}_{2 \mathrm{~A}}-\mathrm{AR}$ in human cardiac tissue in vitro. Furthermore, we found an increased uptake in the initial phase of the in vivo biodistribution of $\left[{ }^{18} \mathrm{~F}\right] \mathrm{FLUDA}$ in the $\mathrm{A}_{2 \mathrm{~A}}$-AR overexpressing mouse model by dynamic PET imaging.

Ishiwata and colleagues provided evidence of the successful non-invasive assessment of $\mathrm{A}_{2 \mathrm{~A}} \mathrm{AR}$ in a human subject by PET imaging using the methylxanthine derivative of KF17837 [ ${ }^{11} \mathrm{C}$ ]TMSX [20]. $\left[{ }^{11} \mathrm{C}\right] \mathrm{TMSX}$ was later used in subsequent studies to compare the $A_{2 A}-A R$ density in hearts between endurance athletes and untrained men $[22,23]$. The non-xanthine derivative $\left[{ }^{18} \mathrm{~F}\right] \mathrm{FESCH}$ was one of the first ${ }^{18} \mathrm{~F}$-labelled $\mathrm{A}_{2 \mathrm{~A}}$-AR PET-imaging probes $[24,25]$, and its deuterated isotopologue $\left[{ }^{18} \mathrm{~F}\right] \mathrm{FLUDA}$ was recently developed and evaluated in vitro as well as in vivo by our group [18]. In the present study, we could show a reduction of the FOC in atrial preparations (stimulated with CGS 21680) from transgenic, but not from wild type mice, after adding FLUDA (Figure 2). Hence, we could confirm the antagonistic action of FLUDA towards the $\mathrm{A}_{2 \mathrm{~A}}$-AR by a functional assay.

In a former study with $\left[{ }^{18} \mathrm{~F}\right] \mathrm{FLUDA}$, we determined a $K_{\mathrm{D}}$ value of $4.30 \pm 0.73 \mathrm{nM}$ and a $B_{\max }$ value of $556 \pm 143 \mathrm{fmol} / \mathrm{mg}$ wet weight in the striatum of healthy CD-1 mice and a $K_{\mathrm{D}}$ value of $0.68 \mathrm{nM}$, as well as a $B_{\max }$ value of $218 \mathrm{fmol} / \mathrm{mg}$ wet weight in the striatum of piglets [18], a brain region with a high $\mathrm{A}_{2 \mathrm{~A}}-\mathrm{AR}$ density. In the human heart, the $A_{2 A}-A R$ is localised at the level of the Z-line of atrial myocytes, where it is co-expressed with $\alpha$-actinin and the ryanodine receptor [26]. In the present study, we determined comparable $\mathrm{A}_{2 \mathrm{~A}}$-AR binding kinetics of $\left[{ }^{18} \mathrm{~F}\right] \mathrm{FLUDA}$ in cardiac cryosections of $\mathrm{A}_{2 \mathrm{~A}}$-AR TG ( $K_{\mathrm{D}}$ of $5.9 \pm 1.6 \mathrm{nM}$ and a $B_{\max }$ of $455 \pm 78 \mathrm{fmol} / \mathrm{mg}$ protein) as in the striatum of healthy male CD-1 mice, although reliable binding kinetic parameters for cardiac cryosections of female FVB/N mice (WT) could not be determined (Figure 3). We assume that the $\mathrm{A}_{2 \mathrm{~A}}-\mathrm{AR}$ density in the cardiac tissue of WT is low and at the edge of the detection limit of $\left[{ }^{18} \mathrm{~F}\right]$ FLUDA, confirming the findings of the functional assays. Binding kinetic studies from other groups with $\left[{ }^{3} \mathrm{H}\right] \mathrm{ZM} 241385$ revealed a higher $\mathrm{A}_{2 \mathrm{~A}}$-AR density in human heart membrane preparations from patients with chronic heart failure (NYHA functional class III and IV, $B_{\max }=210 \pm 8 \mathrm{fmol} / \mathrm{mg}$ protein), which was accompanied with a decreased ligand binding affinity $\left(K_{\mathrm{D}}=2.4 \pm 0.1 \mathrm{nmol} / \mathrm{L}\right)$ when compared to control $\left(B_{\max }=135 \pm 5 \mathrm{fmol} / \mathrm{mg}\right.$ protein, $\left.K_{\mathrm{D}}=0.9 \pm 0.0 \mathrm{nmol} / \mathrm{L}\right)$ [27]. As an initial step in the present study, we determined a low $\mathrm{A}_{2 \mathrm{~A}}$-AR-specific binding with $\left[{ }^{18} \mathrm{~F}\right] \mathrm{FLUDA}$ in the human atrial samples of patients with no diagnosed heart failure (Figure 4), which is in 
accordance with the finding in binding studies in cardiac cryosections of WT mice in this study. Hence, we would also expect a good signal-to-background ratio in humans with an increased $\mathrm{A}_{2 \mathrm{~A}}-\mathrm{AR}$ receptor density in the heart. A direct comparison to heart samples of patients with heart failure and atrial fibrillation should be performed in future studies.

$\mathrm{A}_{2 \mathrm{~A}}$-AR agonists are often used in the clinic to dilate the coronary arteries in patients and to assess the severity and functional consequences of impaired vasodilation in angina pectoris [28]. However, $\left[{ }^{18} \mathrm{~F}\right] \mathrm{FLUDA}$ is not expected to be useful to image the coronary $\mathrm{A}_{2 \mathrm{~A}}-\mathrm{AR}$ density, specifically, as the amount of smooth muscle cells and endothelial cells is much lower compared to the number and volume of cardiomyocytes. Thus, we would expect a binding of $\left[{ }^{18} \mathrm{~F}\right]$ FLUDA mainly to the $\mathrm{A}_{2 \mathrm{~A}}-\mathrm{AR}$ in cardiomyocytes. The in vivo studies in mice revealed increased uptake of $\left[{ }^{18} \mathrm{~F}\right]$ FLUDA under baseline conditions into the myocardium of $\mathrm{A}_{2 \mathrm{~A}}-\mathrm{AR} T \mathrm{TG}$ compared to WT. However, this was restricted to the initial phase after administration of the radioligand. In a single ex vivo autoradiography, we could confirm increased $A_{2 A}-A R$-specific uptake into the myocardia of $A_{2 A}$-AR TG even after $15 \mathrm{~min}$ p.i. (Figure S3). An accumulation over time of $\left[{ }^{18} \mathrm{~F}\right]$ FLUDA into the cardiac tissue of mice could not be observed as it was shown in other studies for $\left[{ }^{11} \mathrm{C}\right] \mathrm{TMSX}$ [20]. Interestingly, in that study, the cardiac uptake of $\left[{ }^{11} \mathrm{C}\right] \mathrm{TMSX}$ was displaceable by just $40 \%$ with carrier and 8-(3-chlorostyryl)caffeine (each in $\mathrm{A}_{2 \mathrm{~A}}$-AR-saturable concentrations), which may be caused by a higher amount of unspecific binding of this tracer, as it was shown for the binding in brain regions with low $\mathrm{A}_{2 \mathrm{~A}}$-AR expression [29,30]. Additionally, it was shown that $60 \mathrm{~min}$ post-injection $\left[{ }^{11} \mathrm{C}\right] \mathrm{TMSX}$ was very stable in human plasma (>90\% intact radioligand), whereas in mice, only $54 \%$ in plasma and $76 \%$ in heart tissue were measured [20]. In a recent study, we found that $71 \%$ of $\left[{ }^{18}\right.$ F]FLUDA was non-metabolised in plasma samples of healthy mice 15 min post-injection [18]. Hence, further studies are needed to clarify a potential enrichment of $\left[{ }^{18}\right.$ F]FLUDA-derived metabolites in the cardiac tissue over time.

Clinical outlook: $\left[{ }^{18} \mathrm{~F}\right]$ FLUDA PET imaging could be useful to assess the receptor occupancy in the heart by $\mathrm{A}_{2 \mathrm{~A}}$-AR-targeting drugs. This might be useful when treating Parkinsonian patients with $\mathrm{A}_{2 \mathrm{~A}}$ antagonists to avoid adverse side effects. Another potential application could be the non-invasive determination of an elevated $\mathrm{A}_{2 \mathrm{~A}} \mathrm{AR}$ density in patients with fibrillation as a diagnostic marker. Hence, it would be possible to establish a cause-effect relationship between $\mathrm{A}_{2 \mathrm{~A}}-\mathrm{AR}$ density and atrial fibrillation in a non-invasive manner in long-term follow-up. The next step will be to test the eligibility of $\left[{ }^{18} \mathrm{~F}\right] \mathrm{FLUDA}$ in patients and to determine the uptake of $\left[{ }^{18} \mathrm{~F}\right]$ FLUDA in the heart.

In summary, we describe a novel radioligand to label and quantify $A_{2 A}$ receptors for diagnostic purposes in the living mammalian heart.

\section{Materials and Methods}

\subsection{General Information}

All chemicals and reagents were purchased from commercially available sources and used without further purification.

The chemical- and radiosynthesis of $\left[{ }^{18} \mathrm{~F}\right]$ FLUDA are described elsewhere [18].

\subsection{Animals}

For the present study, female FVB/N mice $\left(\mathrm{A}_{2 \mathrm{~A}}-\mathrm{AR}\right.$ TG and WT, age: 4-6 months, weight $27 \pm 2 \mathrm{~g}$ ) were used. The generation of the transgenic FVB/N mice overexpressing the human $\mathrm{A}_{2 \mathrm{~A}}-\mathrm{AR}$ under control of an alpha myosin heavy chain promoter in cardiac tissue ( $\left.A_{2 A}-A R T G\right)$, were described elsewhere [21]. In the present study, female $A_{2 A}-A R T G$ and wild type (WT) mice were used in the indicated number. The investigation conforms to the Guide for the Care and Use of Laboratory Animals published by the National Research Council (2011). Animals were handled and maintained according to approved protocols of the animal welfare committee of the University of Münster, Germany. All procedures performed in studies involving animals were in accordance with the ethical standards of 
the institution or practice at which the studies were conducted (Landesdirektion Sachsen, TVV 18/18).

\subsection{Human Atrial Preparations}

Right atrium samples were obtained from patients undergoing open-heart surgery with coronary artery bypass grafts and electrically stimulated in organ baths, as described previously [31,32]. This study complied with the Declaration of Helsinki and was approved by the local ethics committee (hm-bü04.08.2005). All patients gave informed consent.

\subsection{Contractile Function}

The contractile function of mouse left atrial preparations were performed as previously described [21,31]. Control conditions were obtained by $1 \mu \mathrm{g} / \mathrm{mL}$ adenosine deaminase (ADA; Roche Diagnostics Deutschland GmbH, Mannheim, Germany), $1 \mu \mathrm{M}$ of $\mathrm{A}_{1}$ AR antagonist 8-cyclopentyl-1,3-dipropylxanthine (DPCPX; TOCRIS, Bio-Techne GmbH, Wiesbaden-Nordenstadt, Germany), and for the CGS 21680 (Sigma-Aldrich Chemie GmbH, Taufkirchen, Germany) antagonisation, $1 \mu$ M FLUDA instead of $1 \mu$ M ZM 241385 (TOCRIS, Bio-Techne $\mathrm{GmbH}$, Wiesbaden-Nordenstadt, Germany) was used.

\subsection{In Vitro Autoradiography}

Tissues (heart, muscle, and lung) were obtained from FVB/N mice, frozen in isopentane, whereas patient samples were directly frozen in liquid nitrogen. The tissues were cut using a cryostat (MICROM HM560; Fisher Scientific GmbH; Schwerte, Germany), thawmounted onto microscope slides, and, after air-drying, were stored at $-80{ }^{\circ} \mathrm{C}$ until use. The cryosections $(20 \mu \mathrm{m})$ from WT and $\mathrm{hA}_{2 \mathrm{~A}}$-AR TG-mice $(n=3)$ were thawed, dried in a stream of cold air, and preincubated for 15 min with buffer ( $50 \mathrm{mM}$ TRIS-HCl, $\mathrm{pH}$ 7.4, $100 \mathrm{mM} \mathrm{NaCl}, 5 \mathrm{mM} \mathrm{MgCl} 2,1 \mathrm{mM}$ EDTA) containing $1 \mu \mathrm{U} / \mathrm{mL}$ adenosine deaminase (ADA, Sigma) at room temperature. Afterwards, the sections were incubated for $90 \mathrm{~min}$ with $\sim 0.1 \mathrm{MBq} / \mathrm{mL}(96-340 \mathrm{GBq} / \mu \mathrm{mol} ; 0.45-0.97 \mathrm{nM})\left[{ }^{18} \mathrm{~F}\right]-\mathrm{FLUDA}$ (total binding) or with addition of $10 \mu \mathrm{M}$ ZM241385 (non-specific binding). The homologous competition assays were performed in the presence of FLUDA in the concertation range $10^{-6}$ to $10^{-12}$. The sections were then washed twice with ice-cold $50 \mathrm{mM}$ TRIS- $\mathrm{HCl}(\mathrm{pH} 7.4)$, dipped in ice-cold deionised water, dried in a stream of cold air, and exposed overnight on an imaging plate. The plates were scanned using an image plate scanner (HD-CR 35; Duerr NDT GmbH; Bietigheim-Bissingen, Germany). The digitized autoradiograms were analyzed with AIDA 2.31 software (raytest Isotopenmessgeräte $\mathrm{GmbH}$; Straubenhardt, Germany). The $B_{\max }$ and $K_{\mathrm{D}}$ values were calculated from the homologous competition of $\left[{ }^{18} \mathrm{~F}\right]$ FLUDA with FLUDA using the Cheng-Prusoff equation $\left(\mathrm{K}_{\mathrm{D}}=\mathrm{IC} 50-\left[{ }^{18} \mathrm{~F}\right] \mathrm{FLUDA}\right]$ and $\mathrm{B}_{\max }=$ Top - Bottom $\left.\left(\mathrm{K}_{\mathrm{D}}+\left[\left[{ }^{18} \mathrm{~F}\right] \mathrm{FLUDA}\right]\right) /\left[\left[{ }^{18} \mathrm{~F}\right] \mathrm{FLUDA}\right]\right)[33]$. Inhibition curves were created with GraphPad Prism 4.1 (GraphPad Inc.; La Jolla, CA, USA).

Ex vivo autoradiography of the murine hearts was performed immediately after euthanising the animals at $15 \mathrm{~min}$ p.i. of the radioligand. The hearts were isolated, frozen by immersion in isopentane at $-20^{\circ} \mathrm{C}$, cryosectioned (16 $\mu \mathrm{m}$; MICROM HM560), and the dried sections were exposed to a phosphor imaging plate for $120 \mathrm{~min}$ and processed as described above.

\subsection{Small-Animal PET/MR Experiments}

The animals were initially anaesthetised with $5 \%$ isoflurane and were positioned prone into a small-animal PET/MR (nanoScan, MEDISO, Budapest, Hungary) on a temperaturecontrolled bed system $\left(37^{\circ} \mathrm{C}\right)$ while respiration rate was continuously monitored. The anaesthesia (Anaesthesia Unit U-410, agntho's, Lidingö, Sweden) was maintained at $2.1-1.3 \%$ isoflurane in a $60 \%$ oxygen $/ 40 \%$ air gas mixture (Gas blender 100 series, MCQ Instruments, Rome, Italy) with $250 \mathrm{~mL} / \mathrm{min}$ airflow. Prior to the $60 \mathrm{~min}$ PET scan, a scout image MR sequence was performed to outline the animal dimensions. Animals $\left(\mathrm{A}_{2 \mathrm{~A}}-\mathrm{TG}\right.$ and WT) received an i.v. injection of $\left[{ }^{18}\right.$ F]FLUDA (3.5 to $11.3 \mathrm{MBq} ; 1.5$ to $11.3 \mathrm{fmol} / \mathrm{g}$ 
bodyweight). Control animals (WT: $n=6 ; \mathrm{A}_{2 \mathrm{~A}}$-TG: $n=8$ ) received a vehicle solution containing DMSO/Kolliphor/ NaCl, 1:2:7 (v/v/v) $10 \mathrm{~min}$ prior to [ ${ }^{18} \mathrm{~F}$ FLUDA i.v. injection. For the determination of the $\mathrm{A}_{2 \mathrm{~A}} \mathrm{AR}$-specific uptake, animals received an i.v. injection of $2.5 \mathrm{mg} / \mathrm{kg}$ bodyweight tozadenant (WT and $\mathrm{A}_{2 \mathrm{~A}}$-TG: $n=4$ ) or $1 \mathrm{mg} / \mathrm{kg}$ istradyfelline (WT and $\mathrm{A}_{2 \mathrm{~A}}$-TG: $\left.n=3\right) 10$ min prior the radiotracer administration. The data were collected in list mode $(11 \times 10 ; 1 \times 20 ; 5 \times 30 ; 1 \times 45 ; 4 \times 60 ; 1 \times 180 ; 6 \times 300 ; 2 \times 900 \mathrm{~s})$. Subsequently, after the PET scan, a T1-weighted whole-body MR scan (gradient echo sequence, $\mathrm{TR}=20 \mathrm{~ms}, \mathrm{TE}=3.2 \mathrm{~ms}$ ) was performed for anatomical orientation and attenuation correction at the reconstruction step (3D-OSEM, 4 iterations, 6 subsets; MR-based attenuation correction). The reconstructed images were analysed with PMOD (Version 3.802). For analysing the $\left[{ }^{18} \mathrm{~F}\right]$ FLUDA uptake into the myocardium and the activity concentration in the left ventricle (blood compartment), VOIs were delineated in an averaged image of the first $10 \mathrm{~min}$ of the PET imaging after injection of $\left[{ }^{18} \mathrm{~F}\right]$ FLUDA, and co-registered T1 images from MR. Non-parametrical analyses of achieved time-activity curves (TACs) were performed with Microsoft Excel to determine the time to peak, the TAC peak value, and the area-under-the-curve (AUC):

$$
A U C_{0-t(x)}=\int_{0}^{t(x)} c(\text { radioactivity }) \times d t
$$

where $c$ (radioactivity) is expressed as a standardised uptake value normalised to the bodyweight in g (SUV). GraphPad Prism 9 (GraphPad Inc.; La Jolla, CA, USA) was used for graphical presentation.

\subsection{Statistical Analysis}

Values are represented as mean \pm standard error of the mean (SEM). Statistical analyses were performed with Microsoft Excel and GraphPad Prism (v9, San Diego, CA, USA), with $p$-values $\leq 0.05$, calculated by variance analysis (ANOVA) with Bonferroni's post-hoc test or Student's $t$-test if applicable, were considered as significant.

Supplementary Materials: The following are available online at https:/ /www.mdpi.com/article/10 $.3390 /$ ijms23031025/s1.

Author Contributions: D.G., P.B. (Peter Brust) and J.N. designed the study; T.H.L. and R.-P.M. performed organic syntheses; T.H.L. and R.T. performed radiosyntheses; D.G., S.D.-S., W.D.-C., M.T., B.H. and U.G. performed in vivo, ex vivo, and in vitro studies; D.G., S.D.-S., W.D.-C. and U.G. analysed the data; D.G. and J.N. were writing the original draft preparation; M.T., S.D.-S., T.H.L., R.T., W.D.-C., K.K., P.B. (Peter Boknik), U.G. and P.B. (Peter Brust) were reviewing and editing, J.N. and P.B. (Peter Brust) were supervising and administrating the project; P.B. (Peter Brust) was responsible for the funding acquisition. All authors have read and agreed to the published version of the manuscript.

Funding: This work (project no. 100226753) was funded by the European Regional Development Fund (ERDF) and Sächsische Aufbaubank (SAB).

Institutional Review Board Statement: The study was conducted according to the guidelines of the Declaration of Helsinki, the Directive 2010/63/EU of the European Parliament and of the Council of 22 September 2010, on the protection of animals and the German AnimalWelfare Act, and were approved by the responsible authorities of the Free State of Bavaria and the Free State of Saxony (TVV 08/13, 24-9168.11/18/8, 12 June 2013 and TVV 18/18, DD24.1-5131/446/19, 20 June 2018; Landesdirektion Sachsen).

Informed Consent Statement: Informed consent was obtained from all subjects involved in the study.

Data Availability Statement: The data that support the findings of this study are available from the corresponding author upon reasonable request.

Acknowledgments: We are very thankful to K. Franke for providing $\left[{ }^{18} \mathrm{~F}\right]$ fluoride.

Conflicts of Interest: The authors declare no conflict of interest. 


\section{References}

1. Reiss, A.B.; Grossfeld, D.; Kasselman, L.J.; Renna, H.A.; Vernice, N.A.; Drewes, W.; Konig, J.; Carsons, S.E.; DeLeon, J. Adenosine and the Cardiovascular System. Am. J. Cardiovasc. Drugs 2019, 19, 449-464. [CrossRef] [PubMed]

2. Peart, J.N.; Headrick, J.P. Adenosinergic Cardioprotection: Multiple Receptors, Multiple Pathways. Pharmacol. Ther. 2007, 114, 208-221. [CrossRef] [PubMed]

3. Olsson, R.A.; Pearson, J.D. Cardiovascular Purinoreceptors. Physiol. Rev. 1990, 70, 761-845. [CrossRef] [PubMed]

4. Thiel, M.; Caldwell, C.C.; Sitkovsky, M.V. The Critical Role of Adenosine A2A Receptors in Downregulation of Inflammation and Immunity in the Pathogenesis of Infectious Diseases. Microbes Infect. 2003, 5, 515-526. [CrossRef]

5. Dobson, J.G. Reduction by Adenosine of the Isoproterenol-Induced Increase in Cyclic Adenosine 3',5'-Monophosphate Formation and Glycogen Phosphorylase Activity in Rat Heart Muscle. Circ. Res. 1978, 43, 785-792. [CrossRef]

6. Dobson, J.G. Mechanism of Adenosine Inhibition of Catecholamine-Induced Responses in Heart. Circ. Res. 1983, 52, 151-160. [CrossRef]

7. Makujina, S.R.; Sabouni, M.H.; Bhatia, S.; Douglas, F.L.; Mustafa, S.J. Vasodilatory Effects of Adenosine A2 Receptor Agonists CGS 21680 and CGS 22492 in Human Vasculature. Eur. J. Pharmacol. 1992, 221, 243-247. [CrossRef]

8. Tikh, E.I.; Fenton, R.A.; Dobson, J.G. Contractile Effects of Adenosine A1 and A2A Receptors in Isolated Murine Hearts. Am. J. Physiol. Heart Circ. Physiol. 2006, 290, 348-356. [CrossRef]

9. Lasley, R.D.; Kristo, G.; Keith, B.J.; Mentzer, R.M. The A2a/A2b Receptor Antagonist ZM-241385 Blocks the Cardioprotective Effect of Adenosine Agonist Pretreatment in in Vivo Rat Myocardium. Am. J. Physiol. Heart Circ. Physiol. 2007, 292, 426-431. [CrossRef]

10. Llach, A.; Molina, C.E.; Prat-Vidal, C.; Fernandes, J.; Casad, V.; Ciruela, F.; Llus, C.; Franco, R.; Cinca, J.; Hove-Madsen, L. Abnormal Calcium Handling in Atrial Fibrillation Is Linked to Up-Regulation of Adenosine A 2A Receptors. Eur. Heart J. 2011, 32, 721-729. [CrossRef]

11. Molina, C.E.; Llach, A.; Herraiz-Martínez, A.; Tarifa, C.; Barriga, M.; Wiegerinck, R.F.; Fernandes, J.; Cabello, N.; Vallmitjana, A.; Benitéz, R.; et al. Prevention of Adenosine A2A Receptor Activation Diminishes Beat-to-Beat Alternation in Human Atrial Myocytes. Basic Res. Cardiol. 2016, 111, 5. [CrossRef] [PubMed]

12. Asakura, M.; Asanuma, H.; Kim, J.; Liao, Y.; Nakamaru, K.; Fujita, M.; Komamura, K.; Isomura, T.; Fukurawa, H.; Tomoike, H.; et al. Impact of Adenosine Receptor Signaling and Metabolism on Pathophysiology in Patients with Chronic Heart Failure. Hypertens. Res. 2007, 30, 781-787. [CrossRef] [PubMed]

13. da Silva, J.S.; Gabriel-Costa, D.; Sudo, R.T.; Wang, H.; Groban, L.; Ferraz, E.B.; Nascimento, J.H.M.; Fraga, C.A.M.; Barreiro, E.J.; Zapata-Sudo, G. Adenosine A2A Receptor Agonist Prevents Cardiac Remodeling and Dysfunction in Spontaneously Hypertensive Male Rats after Myocardial Infarction. Drug Des. Dev. Ther. 2017, 11, 553-562. [CrossRef] [PubMed]

14. Glover, D.K.; Ruiz, M.; Takehana, K.; Petruzella, F.D.; Rieger, J.M.; Macdonald, T.L.; Watson, D.D.; Linden, J.; Beller, G.A. Cardioprotection by Adenosine A2A Agonists in a Canine Model of Myocardial Stunning Produced by Multiple Episodes of Transient Ischemia. Am. J. Physiol. Heart Circ. Physiol. 2007, 292, H3164-H3171. [CrossRef]

15. Laubach, V.E.; French, B.A.; Okusa, M.D. Targeting of Adenosine Receptors in Ischemia-Reperfusion Injury. Expert Opin. Targets 2011, 15, 103-118. [CrossRef]

16. Sakata, M.; Ishibashi, K.; Imai, M.; Wagatsuma, K.; Ishii, K.; Zhou, X.; de Vries, E.F.J.; Elsinga, P.H.; Ishiwata, K.; Toyohara, J. Initial Evaluation of an Adenosine A 2A Receptor Ligand, 11 C-Preladenant, in Healthy Human Subjects. J. Nucl. Med. 2017, 58, 1464-1470. [CrossRef]

17. Barret, O.; Hannestad, J.; Vala, C.; Alagille, D.; Tavares, A.; Laruelle, M.; Jennings, D.; Marek, K.; Russell, D.; Seibyl, J.; et al. Characterization in Humans of ${ }^{18}$ F-MNI-444, a PET Radiotracer for Brain Adenosine 2A Receptors. J. Nucl. Med. 2015, 56, 586-591. [CrossRef]

18. Lai, T.H.; Toussaint, M.; Teodoro, R.; Dukić-Stefanović, S.; Gündel, D.; Ludwig, F.; Wenzel, B.; Schröder, S.; Sattler, B.; Moldovan R.-P.; et al. Improved in vivo PET Imaging of the Adenosine $\mathrm{A}_{2 \mathrm{~A}}$ Receptor in the Brain Using [ ${ }^{18}$ F]FLUDA, a Deuterated Radiotracer with High Metabolic Stability. Eur. J. Nucl. Med. Mol. Imaging 2021, 48, 2727-2736. [CrossRef]

19. Ishiwata, K.; Sakiyama, Y.; Sakiyama, T.; Shimada, J.; Toyama, H.; Oda, K.; Suzuki, F.; Senda, M. Myocardial Adenosine A2a Receptor Imaging of Rabbit by PET with [11C]KF17837. Ann. Nucl. Med. 1997, 11, 219-225. [CrossRef]

20. Ishiwata, K.; Kawamura, K.; Kimura, Y.; Oda, K.; Ishii, K. Potential of an Adenosine A2A Receptor Antagonist [ 11C]TMSX for Myocardial Imaging by Positron Emission Tomography: A First Human Study. Ann. Nucl. Med. 2003, 17, 457-462. [CrossRef] [PubMed]

21. Boknik, P.; Drzewiecki, K.; Eskandar, J.; Gergs, U.; Grote-Wessels, S.; Fabritz, L.; Kirchhof, P.; Müller, F.U.; Stümpel, F.; Schmitz, W.; et al. Phenotyping of Mice with Heart Specific Overexpression of A2A-Adenosine Receptors: Evidence for Cardioprotective Effects of A2A-Adenosine Receptors. Front. Pharmacol. 2018, 9, 13. [CrossRef] [PubMed]

22. Heinonen, I.; Nesterov, S.V.; Liukko, K.; Kemppainen, J.; Någren, K.; Luotolahti, M.; Virsu, P.; Oikonen, V.; Nuutila, P.; Kujala, U.M.; et al. Myocardial Blood Flow and Adenosine A2A Receptor Density in Endurance Athletes and Untrained Men. J. Physiol. 2008, 586, 5193-5202. [CrossRef] [PubMed]

23. Mizuno, M.; Kimura, Y.; Tokizawa, K.; Ishii, K.; Oda, K.; Sasaki, T.; Nakamura, Y.; Muraoka, I.; Ishiwata, K. Greater Adenosine A2A Receptor Densities in Cardiac and Skeletal Muscle in Endurance-Trained Men: A [11C]TMSX PET Study. Nucl. Med. Biol. 2005, 32, 831-836. [CrossRef] [PubMed] 
24. Khanapur, S.; Paul, S.; Shah, A.; Vatakuti, S.; Koole, M.J.B.; Zijlma, R.; Dierckx, R.A.J.O.; Luurtsema, G.; Garg, P.; van Waarde, A.; et al. Development of [18F]-Labeled Pyrazolo[4,3-e ]-1,2,4-Triazolo[1, 5-c ]Pyrimidine (SCH442416) Analogs for the Imaging of Cerebral Adenosine A 2A Receptors with Positron Emission Tomography. J. Med. Chem. 2014, 57, 6765-6780. [CrossRef]

25. Khanapur, S.; van Waarde, A.; Dierckx, R.A.J.O.; Elsinga, P.H.; Koole, M.J.B. Preclinical Evaluation and Quantification of ${ }^{18} \mathrm{~F}-$ Fluoroethyl and ${ }^{18}$ F-Fluoropropyl Analogs of SCH442416 as Radioligands for PET Imaging of the Adenosine $\mathrm{A}_{2 \mathrm{~A}}$ Receptor in Rat Brain. J. Nucl. Med. 2017, 58, 466-472. [CrossRef] [PubMed]

26. Hove-Madsen, L.; Prat-Vidal, C.; Llach, A.; Ciruela, F.; Casadó, V.; Lluis, C.; Bayes-Genis, A.; Cinca, J.; Franco, R. Adenosine A2A Receptors Are Expressed in Human Atrial Myocytes and Modulate Spontaneous Sarcoplasmic Reticulum Calcium Release. Cardiovasc. Res. 2006, 72, 292-302. [CrossRef]

27. Varani, K.; Laghi-Pasini, F.; Camurri, A.; Capecchi, P.L.; Maccherini, M.; Diciolla, F.; Ceccatelli, L.; Enea Lazzerini, P.; Ulouglu, C.; Cattabeni, F.; et al. Changes of Peripheral A 2A Adenosine Receptors in Chronic Heart Failure and Cardiac Transplantation. FASEB J. 2003, 17, 280-282. [CrossRef]

28. Elkholy, K.O.; Hegazy, O.; Okunade, A.; Aktas, S.; Ajibawo, T. Regadenoson Stress Testing: A Comprehensive Review With a Focused Update. Cureus 2021, 13, e15940. [CrossRef]

29. Ishiwata, K.; Noguchi, J.; Wakabayashi, S.; Shimada, J.; Ogi, N.; Nariai, T.; Tanaka, A.; Endo, K.; Suzuki, F.; Senda, M. 11C-Labeled KF18446: A Potential Central Nervous System Adenosine A2a Receptor Ligand. J. Nucl. Med. Off. Publ. Soc. Nucl. Med. 2000, 41, 345-354.

30. Naganawa, M.; Kimura, Y.; Mishina, M.; Manabe, Y.; Chihara, K.; Oda, K.; Ishii, K.; Ishiwata, K. Quantification of Adenosine A2A Receptors in the Human Brain Using [11C]TMSX and Positron Emission Tomography. Eur. J. Nucl. Med. Mol. Imaging 2007, 34, 679-687. [CrossRef]

31. Gergs, U.; Büxel, M.L.; Bresinsky, M.; Kirchhefer, U.; Fehse, C.; Höring, C.; Hofmann, B.; Marusakova, M.; Čináková, A.; Schwarz, R.; et al. Cardiac Effects of Novel Histamine $\mathrm{H}_{2}$ Receptor Agonists. J. Pharmacol. Exp. Ther. 2021, 379, 223-234. [CrossRef] [PubMed]

32. Gergs, U.; Rothkirch, D.; Hofmann, B.; Treede, H.; Robaye, B.; Simm, A.; Müller, C.E.; Neumann, J. Mechanism Underlying the Contractile Activity of UTP in the Mammalian Heart. Eur. J. Pharmacol. 2018, 830, 47-58. [CrossRef] [PubMed]

33. Motulsky, H. The GraphPad Guide to Analyzing Radioligand Binding Data; GraphPad: San Diego, CA, USA, 1995. 